\title{
Konstytucyjne aspekty procesu karnego w działalności Rzecznika Praw Obywatelskich
}

\begin{abstract}
The changes in the broadly conceived criminal procedure which were introduced in recent years refer to the problems which are crucial from the perspective of the protection of human rights, such as the scope of the authority of the services due to operational control which is conducted secretly, the model of the functioning of the public prosecution service or the unlawful acquiring of evidence in a criminal procedure. The evaluation of these changes, conducted by the Ombudsman from the point of view of the constitutional standards of the protection of the rights of the individual is not positive. The new regulations reduce the quality of these standards and they do not contain sufficient guarantees of protection against the arbitrariness of the activities engaged in these terms by the organs of public authority. This phenomenon imposes a particular duty on the courts - which hear criminal cases - to see that the final decision in a criminal case respects the universal standards of the protection of human rights.
\end{abstract}

Key words: human rights, the protection of the rights of the individual, operational control, illegal evidence

Zmiany wprowadzane $\mathrm{w}$ ostatnim czasie $\mathrm{w}$ obowiązującym prawie dotyczą tak kluczowych z punktu widzenia ochrony praw jednostki zagadnień jak: zakres uprawnień przysługujących poszczególnym służbom w związku z zarządzaną kontrolą operacyjną oraz sięganiem przez te służby w sposób niejawny po dane telekomunikacyjne, model funkcjonowania prokuratury czy też model pozyskiwania w postępowaniu karnym dowodów z naruszeniem przepisów postępowania lub za pomocą czynu zabronionego. Wszystkie te zagadnienia, jako że bezpośrednio dotyczą sfery ochrony praw człowieka, stanowią przedmiot zainteresowania i oceny ze strony Rzecznika Praw Obywatelskich. Ocena ta jest dokonywana przede wszystkim z punktu widzenia dochowania przez polskie prawo- 
dawstwo standardów wynikających z Konstytucji RP oraz z Europejskiej Konwencji o Ochronie Praw Człowieka i Podstawowych Wolności. Ocena ta, niestety, nie wypada pozytywnie, Rzecznik dostrzega bowiem szereg zagrożeń dla praw lub wolności człowieka, których źródłem jest obowiązujące prawodawstwo.

Ramy wystąpienia nie pozwalają na szczegółowe przedstawienie wszystkich zagadnień, które są przedmiotem zainteresowania Rzecznika. Stąd też jedynie w formie przykładu trzeba zwrócić uwagę na Ustawę z dnia 15 stycznia 2016 r. o zmianie ustawy o Policji oraz niektórych innych ustaw (Dz.U. poz. 147), na tle której ujawniły się problemy konstytucyjne dotyczące niejawnej ingerencji przez poszczególne służby w prawa podmiotowe jednostki. Ustawa ta miała służyć wykonaniu wyroku Trybunału Konstytucyjnego z dnia 30 lipca 2014 r. (sygn. akt K 23/11), jednak jej przepisy nie tylko nie realizują tego wyroku, lecz wręcz prowadzą do utrwalenia stanu naruszenia konstytucyjnych wolności lub praw człowieka oraz standardów wyznaczonych przez prawo międzynarodowe. Wątpliwości konstytucyjne, zwłaszcza w kontekście wspomnianego wyro$\mathrm{ku}$, budzą przepisy pozwalające poszczególnym służbom na pozyskiwanie danych telekomunikacyjnych, danych pocztowych oraz danych internetowych nie stanowiących treści przekazu, a także zezwalające na przetwarzanie tych danych bez wiedzy i zgody osoby, której dotyczą. Uprawnienia do ich pozyskiwania zostały przyznane poszczególnym służbom w celu zapobiegania lub wykrywania przestępstw albo w celu ratowania życia lub zdrowia ludzkiego bądź wsparcia działań poszukiwawczych lub ratowniczych.

Zastrzeżenia z punktu widzenia konstytucyjnego standardu ochrony prawa do prywatności wywołuje to, że cel pozyskiwania danych został określony zbyt szeroko (dane są pozyskiwane „w celu zapobiegania lub wykrywania przestępstw"). Tymczasem ograniczenie prawa do prywatności czy też uszczegółowionego jego komponentu w postaci wolności i tajemnicy komunikowania się może nastąpić - jak wskazuje Konstytucja - jedynie w przypadkach określonych w ustawie. Ustawa musi zatem zapewnić w tym zakresie odpowiednią precyzję i nie może odwoływać się do tak pojemnych katalogów jak ogólne pojęcie „przestępstwa”; musi wskazywać w każdym przypadku, jakie konkretne czyny zabronione uzasadniają niejawne pozyskiwanie danych o jednostce. Ta myśl znalazła swój wyraz w wyroku Trybunału Sprawiedliwości Unii Europejskiej z dnia 8 kwietnia 2014 r. w połączonych sprawach: Digital Rights Ireland (C-293/12) i Kärtner Landesregierung i in. (C-594/12), dotyczacym retencji danych telekomunikacyjnych, w którym to wyroku stwierdzono naruszenie wymogu proporcjonalności ingerencji w prawo do prywatności i prawo do ochrony danych osobowych. 
Również wprowadzona tymi przepisami kontrola sądowa niejawnych czynności dotyczących pozyskiwania danych telekomunikacyjnych ma charakter pozorny. Sąd otrzymuje bowiem jedynie zbiorczą informację na temat pozyskanych przez służby danych. Nie dysponuje on natomiast żadnym efektywnym narzędziem pozwalającym na ochronę praw jednostki. Ustawodawca zezwala bowiem sądowi wyłącznie na poinformowanie odpowiednich służb o wynikach kontroli, nie zezwala zaś np. na zarządzenie zniszczenia danych, które zostały zebrane w sposób sprzeczny z ustawą, co stanowiłoby narzędzie umożliwiające realizację prawa wynikającego $\mathrm{z}$ art. 51 ust. 4 Konstytucji RP, a więc prawa do usunięcia informacji zebranych w sposób sprzeczny z ustawą. Ponadto ustanowiona procedura kontrolna musi budzić zastrzeżenia $\mathrm{w}$ kontekście powołanego wyroku TSUE z dnia 8 kwietnia 2014 r. W wyroku tym TSUE opowiedział się za uprzednią kontrolą sądu lub innego niezależnego organu, który pilnowałby, aby udostępnianie i wykorzystywanie danych ograniczało się do przypadków, gdy jest to ściśle konieczne dla realizacji zamierzonego celu. Brak uprzedniej kontroli sądu lub niezależnego organu TSUE uznał za nieuzasadnioną ingerencję w prawa określone w Karcie Praw Podstawowych UE.

Mając na uwadze opisane powyżej naruszenia standardów ochrony podstawowych wolności i praw jednostki, Rzecznik Praw Obywatelskich w dniu 18 lutego 2016 r. zwrócił się do Trybunału Konstytucyjnego o kontrolę konstytucyjności owych nowych rozwiązań dotyczących niejawnego pozyskiwania informacji przez poszczególne służby (sprawa zawisła przed Trybunałem Konstytucyjnym pod sygn. akt K 9/16).

Poważne zastrzeżenia budzi także nowe brzmienie art. 168a k.p.k. nadane ustawą z dnia 11 marca 2016 r. o zmianie ustawy - Kodeks postępowania karnego oraz niektórych innych ustaw (Dz.U. poz. 437). Stanowi on, że dowodu nie można uznać za niedopuszczalny wyłącznie na tej podstawie, iż został on uzyskany z naruszeniem przepisów postępowania lub za pomocą czynu zabronionego, chyba że dowód został uzyskany w związku z pełnieniem przez funkcjonariusza publicznego obowiązków służbowych w wyniku: zabójstwa, umyślnego spowodowania uszczerbku na zdrowiu lub pozbawienia wolności. Na tle tego przepisu powstaje uzasadniona wątpliwość, czy w świetle standardów konstytucyjnych (w tym prawa do sprawiedliwego rozpatrzenia sprawy przez sąd) dopuszczalne jest, aby organ państwa mógł oprzeć akt oskarżenia, czy też inne czynności procesowe, na dowodach uzyskanych niezgodnie z prawem, w tym na dowodach uzyskanych $\mathrm{w}$ wyniku popełnienia czynu zabronionego. Z perspektywy zasady praworządności wyrażonej w art. 7 Konstytucji RP art. 168a k.p.k. podważa tę zasadę. Obala bowiem konstytucyjne domniemanie, że organy państwa działają na podstawie i w granicach prawa. Ustawodawca przyjął, że organy władzy publicznej, odpowiadające prze- 
cież za praworządne postępowanie, mogą działać w sposób niezgodny z prawem, natomiast wymiar sprawiedliwości powinien akceptować te niepraworządne działania.

Art. 168a k.p.k. narusza też konstytucyjne prawo do obrony, gdyż uniemożliwia przewidzenie sposobu działania oskarżyciela publicznego, który wcale nie musi działać w granicach prawa i na jego podstawie. Natomiast nałożenie na sąd obowiązku uwzględnienia dowodu uzyskanego w sposób niezgodny z przepisami prawa lub za pomocą czynu zabronionego daje organom prowadzącym postępowanie karne możliwość wnioskowania o włączenie dowodów, które zostały pozyskane w sposób wypełniający znamiona tortur lub okrutnego, nieludzkiego albo poniżającego traktowania, co pozostaje w kolizji z art. 40 Konstytucji RP oraz z art. 3 Europejskiej Konwencji o Ochronie Praw Człowieka i Podstawowych Wolności. Niedopuszczalność korzystania w procesie z dowodów pozyskanych nielegalnie, z naruszeniem art. 3 Europejskiej Konwencji, potwierdził Europejski Trybunał Praw Człowieka m.in. w wyroku z dnia 1 czerwca 2010 r. w sprawie Gäfgen p. Republice Federalnej Niemiec (skarga nr 54810/00), stwierdzając, że z procesu należy wyłączyć nie tylko wyjaśnienia złożone pod przymusem, ale także dowody rzeczowe uzyskane dzięki tym wyjaśnieniom.

W efekcie stwierdzonych i opisanych powyżej naruszeń Rzecznik Praw Obywatelskich w dniu 6 maja 2016 r. zwrócił się do Trybunału Konstytucyjnego o ocenę art. 168a k.p.k. z punktu widzenia konstytucyjnych standardów ochrony praw jednostki (sprawa o sygn. akt K 27/16).

Wskazać jednak trzeba, że sądy poszukują takiej wykładni prawa w obszarze objętym oddziaływaniem art. 168a k.p.k., która jest w stanie zapewnić ochronę standardu konstytucyjnego i standardu wynikającego z Europejskiej Konwencji o Ochronie Praw Człowieka i Podstawowych Wolności. Przykładowo w wyroku z dnia 27 kwietnia 2017 r. (sygn. akt II AKa 213/16) Sąd Apelacyjny we Wrocławiu uznał, że dowód może zostać uznany za niedopuszczalny, jeżeli został wyzyskany z naruszeniem przepisów postępowania lub za pomocą czynu zabronionego przy jednoczesnym naruszeniu przepisów Konstytucji. W takiej sytuacji - zdaniem sądu - ograniczenie ustawowe wyrażone zwrotem „wyłącznie na tej podstawie, że został uzyskany z naruszeniem przepisów postępowania lub za pomocą czynu zabronionego" nie ma zastosowania, gdyż naruszone w tym zakresie zostały także normy prawa konstytucyjnego.

W omawianym kontekście zwrócić też trzeba uwagę na art. 137 \$2 Ustawy z dnia 28 stycznia 2016 r. - Prawa o prokuraturze (Dz.U. 2017, poz. 1767 ze zm.), zgodnie z którym nie stanowi przewinienia dyscyplinarnego działanie lub zaniechanie prokuratora podjęte wyłącznie w interesie społecznym. Oznacza to, że prokurator nie ponosi odpowiedzialności 
dyscyplinarnej za oczywistą i rażącą obrazę przepisów prawa i uchybienie godności urzędu, jeśli działał wyłącznie w interesie społecznym.

Art. 137 \$2 Prawa o prokuraturze, ustanawiając ten swoisty kontratyp odpowiedzialności dyscyplinarnej, nie przewiduje jakiegokolwiek ważenia wartości. Nie ma więc znaczenia to, czy interes społeczny był na tyle ważny, że uzasadniał dopuszczenie się oczywistej i rażącej obrazy przepisów prawa. Stąd też każde działanie lub zaniechanie prokuratora uczynione wyłącznie $\mathrm{w}$ interesie społecznym nie stanowi przewinienia dyscyplinarnego niezależnie od wagi dobra, które zostanie naruszone w wyniku tego działania lub zaniechania. W istocie więc przepis ten wyraża kolektywistyczną wizję prawa, w której dobro zbiorowe ma zawsze przewagę nad dobrem jednostki.

Należy również zwrócić uwagę na inny aspekt redakcji art. 137 §2 Prawa o prokuraturze. Otóż obowiązek przestrzegania prawa przez prokuratora ma swój konstytucyjny wymiar (art. 7 Konstytucji RP), dlatego oczywista i rażąca obraza przepisów prawa stanowi nie tylko naruszenie praw jednostki, lecz mieści się także w kategorii naruszenia interesu społecznego. $\mathrm{W}$ interesie społecznym leży przecież to, aby prokurator przestrzegał prawa, nie uchybiał godności urzędu i nie dopuszczał się przewinień służbowych. Trywializując nieco problem, art. 137 § 2 Prawa o prokuraturze można także odczytać w ten sposób, że nie stanowi naruszenia interesu społecznego (chociaż obiektywnie do takiego naruszenia doszło) działanie podjęte wyłącznie w interesie społecznym. Stąd też Rzecznik Praw Obywatelskich w dniu 5 sierpnia 2016 r. zdecydował się zaskarżyć ten przepis do Trybunału Konstytucyjnego (sprawa o sygn. akt K 42/16).

Gwarancje prawa do sądu narusza ponadto brak możliwości zaskarżenia do sądu postanowienia prokuratora o zarządzeniu ekshumacji (art. 210 k.p.k.). Ekshumacja zwłok i szczątków ludzkich dokonywana na zarządzenie prokuratora stanowi władcze wkroczenie w sferę prawnie chronionych dóbr osobistych w postaci kultu osoby zmarłej. Oznacza to, że osobom bliskim muszą służyć środki prawne w celu ustalenia, czy wkroczenie przez prokuratora $\mathrm{w}$ tę prawnie chronioną sferę nie ma charakteru ekscesywnego. Każda osoba, która uważa, że jej konstytucyjne prawo do prywatności (art. 47 Konstytucji RP) zostało naruszone w wyniku zarządzenia ekshumacji, musi mieć możliwość skorzystania z sądowej ochrony prawnej. Jak bowiem wskazał Trybunał Konstytucyjny w uzasadnieniu do wyroku z dnia 3 lipca 2008 r. (sygn. akt K 38/07) w konstytucyjnym pojęciu sprawy w rozumieniu art. 45 ust. 1 Konstytucji RP mieszczą się zagadnienia dotyczące rozstrzygnięć prokuratorskich związanych z prawem do prywatności. Stąd też ustawa nie może zamykać drogi sądowej w przypadku, gdy osoba bliska uważa, że zarządzenie przez pro- 
kuratora ekshumacji narusza kult osoby zmarłej. Jednak aktualnie obowiązujące przepisy k.p.k. (art. $210 \mathrm{i}$ art. 459 §2) nie przewidują zażalenia na zarządzenie ekshumacji, co narusza art. 45 ust. 1 Konstytucji RP. Takie też stanowisko przedstawił Rzecznik Praw Obywatelskich osobom, które zwracały się do niego w związku z zarządzanymi przez prokuraturę ekshumacjami ofiar katastrofy smoleńskiej. Przedstawiona przez Rzecznika Praw Obywatelskich argumentacja posłużyła do wszczęcia przez te osoby przed Europejskim Trybunałem Praw Człowieka postępowania mającego na celu ochronę ich praw (sprawy E. Solska i M. Rybicka p. Polsce, skargi nr 30491/17 i 31083/17).

Liczne wątpliwości natury konstytucyjnej dotyczą ponadto przepisów regulujących pozaprocesowe stosowanie kontroli operacyjnej przez Policję oraz pozostałe służby, a także art. 168b i art. 237a k.p.k., będących wynikiem nowelizacji dokonanej ustawą z dnia 11 marca 2016 r. o zmianie ustawy - Kodeks postępowania karnego oraz niektórych innych ustaw i wprowadzających całkowicie nowe zasady wyrażania zgody następczej na wykorzystanie $\mathrm{w}$ postępowaniu karnym materiałów uzyskanych w wyniku kontroli operacyjnej, dotyczących innego przestępstwa lub innej osoby niż objęte sądową kontrolą operacyjną. Również wiele przepisów ustawy z dnia 10 czerwca 2016 r. o działaniach antyterrorystycznych (Dz.U. poz. 904) narusza prawo do prywatności i autonomię informacyjną jednostki, a także prawo do sądu. Sprawy te w wyniku działań podjętych przez Rzecznika Praw Obywatelskich (wnioski do Trybunału Konstytucyjnego z dnia 29 kwietnia 2016 r. oraz z dnia 11 lipca 2016 r. są przedmiotem rozpoznania przez Trybunał Konstytucyjny - sygn. akt K 24/16 i K 35/16).

Także ostatnie propozycje legislacyjne, zawarte m.in. w przedstawionym przez Prezydenta RP projekcie ustawy o Sądzie Najwyższym, wywołują wątpliwości konstytucyjne. Projekt ustawy o Sądzie Najwyższym przewiduje m.in. wprowadzenie skargi nadzwyczajnej, co spowoduje, że $\mathrm{w}$ istotnej części spraw sądowych dopuszczalne będzie postępowanie w czterech instancjach, przy czym dwa szczeble tego postępowania będą obejmowały postępowanie nadzwyczajne już po uprawomocnieniu się orzeczenia sądowego, tj. postępowanie kasacyjne i postępowanie ze skargi nadzwyczajnej wnoszonej przez uprawione podmioty. Już sama ta okoliczność budzi wątpliwości z punktu widzenia rzeczywistej realizacji prawa stron postępowania sądowego do rozpatrzenia ich sprawy w rozsądnym terminie, skoro nawet nadzwyczajne postępowanie kasacyjne nie zawsze będzie kończyło definitywnie sprawę.

Proponowany model skargi nadzwyczajnej budzi także zasadnicze wątpliwości z perspektywy osób, które były oskarżone w procesie karnym. $Z$ art. $524 \S 3$ k.p.k. wynika, że niedopuszczalne jest uwzględnienie 
kasacji na niekorzyść oskarżonego wniesionej po upływie roku od daty uprawomocnienia się orzeczenia. Jednak to, co jest niedopuszczalne w postępowaniu kasacyjnym, według zamysłu projektodawcy staje się następnie dopuszczalne w postępowaniu ze skargi nadzwyczajnej. Z art. 86 §1 projektu wynika bowiem, że niedopuszczalne jest uwzględnienie skargi nadzwyczajnej na niekorzyść oskarżonego po upływie 6 miesięcy od rozpoznania kasacji. W ten sposób zawarta w art. 524 § 3 k.p.k. gwarancja dla osoby oskarżonego traci na znaczeniu, co stanowi naruszenie konstytucyjnej zasady zaufania obywatela do państwa i stanowionego prawa (art. 2 Konstytucji RP). To, co z woli ustawodawcy wyrażonej w przepisach k.p.k. jest i w dalszym ciągu będzie niedopuszczalne, stanie się dopuszczalne na mocy proponowanego modelu skargi nadzwyczajnej.

Przedstawione przykłady wskazują, że obecnie funkcjonują (bądź są projektowane) przepisy, które budzą istotne zastrzeżenia z punktu widzenia konstytucyjnych standardów ochrony praw jednostki. Nakłada to na sądy rozpoznające sprawy karne szczególny obowiązek dbania o to, aby finalne rozstrzygnięcie wydawane w sprawach karnych respektowały owe standardy, co w wielu wypadkach wymaga dokonywania wykładni ustaw w zgodzie z Konstytucją oraz z Europejską Konwencją o Ochronie Praw Człowieka i Podstawowych Wolności, ewentualnie odmowy zastosowania ustawy, jeśli nie da się jej pogodzić z Europejską Konwencją (art. 91 ust. 2 Konstytucji RP). Europejska Konwencja ma bowiem pierwszeństwo przed ustawą, jeżeli ustawy nie da się z nią pogodzić. 